\title{
'Vs for to wepe no man may lett': Accommodating Female Grief in the Medieval English Lazarus Plays ${ }^{1}$
}

In the N-Town cycle's Raising of Lazarus, as soon as Lazarus is interred, Mary Magdalene declares to her sister Martha, 'Lete us sytt down here by pe grave / or we go hens wepe all oure fylle' (167-8). ${ }^{2}$ Martha joins her, proclaiming, 'Vs for to wepe no man may lett' (169). Their exchange suggests that they expect their weeping to provoke opposition, and it does. Four male consolers, outraged by the sisters' conduct, take turns chastising them, denouncing their behavior as shameful and offensive: 'Arys for shame ze do not ryght / streyth from pis grave ze xul go hens / pus for to grugge ageyns godys myght / Azens hy3 god ze do offens' (173-6). The consolers seem unduly scandalized. How can women's tears offend one so powerful as God? But Martha explicitly poses the sisters' mourning at the grave as a form of resistance to male control, and the consolers respond in kind. They view the sisters' mourning as potent, a dangerous affront that must be curtailed. The public nature of this confrontation - in the open, at the gravesite - implies that the sisters' laments have a rhetorical appeal that the consolers find threatening to their position as the self-appointed spokesmen of 'godys myght'.

This gendered conflict between two discourses, female grief and male control, so clearly delineated in the N-Town cycle, manifests itself, albeit more subtly and in different ways, in all of the extant manuscripts of the medieval English Lazarus plays. But there is more at stake here than gender. In its deep structure it is an encounter between two different constructions of death and mourning: the dominant Christian belief that faith in God brings eternal life, and therefore one should not grieve over the dead; and the residual practice of lament for the dead, an oral tradition usually led by women in which 'eternal life' - living on in the memory of the community - depends upon repetitive performances of mourning. ${ }^{3}$ As a social practice presided over by women, ritual lament poses resistence to male social authority and the tenets of the dominant Christian ideology. 
In his poetically astute reading of the Corpus Christi Passion plays Peter Dronke argues that the characterization of the mourning Virgin Mary, the Planctus Mariae, draws upon this tradition of residual lament: 'the nature of the texts we have suggests ... that the lament of Mary was not primarily a learned invention at all. On the contrary, when these laments surface in the learned world, they still bear all the marks of a non-theological genre and lyric impulse, the marks of a traditional type of woman's lament.'4 Dronke perceives several prominent features of female lament in his analysis of the medieval Planctus: Mary's love for life expressed her laments for the decay of Christ's physical beauty; the frequent use of direct address, a key rhetorical feature of lament; and Mary's 'unredeemable grief' (116), which prevails over the Christian promise of salvation. He points to the dissonance of Mary's tone in the Christian context of the Passion plays, for her 'bitterness is unrelieved' (116). Instead of affirming the 'truth of the Redemption', Mary's 'sorrowing remains unabated to the end' (116). Dronke observes that Mary's 'unredeemable grief' is evidence of 'a particularly forceful resurgence of the ancient non-theological traditions of women's laments' (116).

As Dronke's observations indicate, the genre of female lamentation encompasses the idea that grief, or mourning, is an obligatory performance with clear rhetorical features. ${ }^{5}$ An ancient practice, reaching back beyond the historical records of archaic Greece, lamentation for the dead continues today in parts of eastern Europe, Africa, and the Mediterranean. ${ }^{6}$ A public performance that is usually led by the close female relatives of the deceased, its purpose is to articulate and therefore also contain the impending chaos that can accompany the intense emotions and altered social structure of a community that attends the death of one of its members. ${ }^{7}$ The lamenters' narratives about the deceased, punctuated by shrieks and wails, honour and appease the spirit of the dead, assisting the soul in its journey through the afterlife. The stages of the body's passage, first in the home immediately after death, then in the burial procession, and finally at the grave where it is incorporated into the earth, mirror the condition of the bereaved community. Distinct rhetorical figures and gestures perform the emotions of rage, helplessness, and fear attendant upon death. Through direct address, interrogative apostrophes, incantations, wails, and shrieks the female lamenters are believed to commune with the spirit of the dead at the same time that they articulate the emotions and anxieties of their respective communities. Gestures of self-mutilation tearing the hair and rending the face - align the mourners with the dead: just as death disfigures the body, so the mourners disfigure themselves. Lamenters wish for death and sit on the ground near the grave, denying separation and 
participating in the state of the dead. Their performance articulates social disorder and physical decay as a precondition for social regeneration and renewal. Because lamentation is an oral performative genre, its efficacy depends upon repetition to sustain the presence of the deceased in the cultural memory: the essence of ritual lamentation is therefore expressed in its most common motif, unforgettable or inconsolable grief.

The persistence of ritual lament, or 'wailing the dead' as it was known in England, is demonstrated by depictions of mourning and death in literature and widely scattered denunciations of the practice into the early years of the seventeenth century. ${ }^{8}$ Denunciations of weeping over the dead are especially prevalent in sermons and treatises in the first decades of the reformation. The early protestant tirades against lament show that it coexisted with catholic practices. Protestant prelates refer to the customs as both 'popish' and 'heathen'. Matthew Parker, the future archbishop of Canterbury, used his 1551 funeral sermon for Martin Bucer as an occasion to exhort his parishioners to reform their mourning customs: 'It agreeth not with the rules of faith, for a Christian man to bewalye the dead. For who can deny that to be against faith, which is flatly forbidden by the scriptures.' He admonishes his English audience to refrain from 'wommanish wayling, and childish infirmitie ... for it is both unseemly and wicked to use any howling or blubbering for him, unlesse we desire to be accounted creatures rather beastly in nature than furnished with the use of reason.' ${ }^{9}$ Hugh Latimer proclaims in his 1553 Lincolnshire sermon, 'In the time of popery, before the gospel came amongst us, we went to buriales, with wepyng and wailing, as thoughe there were no god.' ${ }^{10}$ Similarly, Thomas Becon's dying man asserts, 'Let the infideles mourne for their dead: the Christian ought to reioyse, whan anye of the faithfull be called from this vale of misery unto the glorious kingdom of God.' ${ }^{11}$ An anonymous treatise from the middle of the sixteenth century admonishes the English, 'We muste not lamente and mourne of ungodlynesse and superstycion, as the unfaythefull heathen do whiche beleve not the resurrecyon of the dead.' 12

An ecclesiastical record from 1590 documents a mourning ritual in Lancaster England that bears a striking resemblance to that of the N-Town Lazarus and other medieval accounts of mourning the dead. The record refers to 'enormities and abuses' and 'superstition used in the burial of the dead' by the local community: 'And when the corpse is ready to be put into the grave, some by kissing the dead corpse, others by wailing the dead with more than heathenish outcries, others with open invocations for the dead, and another sort with jangling the bells, so disturb the whole action, that the minister is 
oft compelled to let pass that part of the service and to withdraw himself from their tumultuous assembly.' 13 In the N-Town Lazarus Martha and Mary wail loudly as their brother is interred, and Mary kisses his grave before she departs. The play is also structured around the four phases of residual lament: lament in the home, during the procession to the grave, at the grave, and following the burial. In the Digby Mary Magdalene, Mary refers to the custom of carrying the corpse to the grave accompanied by weepers, a practice resembling the final burial scene in the Alliterative Morte d'Arthur. ${ }^{14}$ Numerous references in sermons, consolatory letters, and literature throughout the sixteenth century indicate that ritual lament, or 'wailing the dead' as it was known colloquially, was a deeply ingrained if residual mourning practice that was at least partially acculturated to Catholicism, continuing in parts of England for at least a generation after the Reformation.

Two defining features of ritual lament are in tension with the central tenets of Christian eschatology. Inconsolable grief seems to subvert the Christian promise of redemption and eternal life, and the belief that women's cries could commune with the dead challenges the Christian belief in Jesus as the mediator between the human and heavenly realms. The medieval English Lazarus plays, even more than the Passion plays, manifest ambivalence in attempting to reconcile these opposed systems of value. In the Passion plays Mary's laments for Christ, despite the resistant sentiments noted by Dronke, align themselves with the religious pedagogy that construed weeping for Christ as a sign of compunction for sin. ${ }^{15}$ While the Planctus is non-biblical, the doctrine of Mary's 'Compassion', her share in Christ's suffering through her mourning, assimilated this resistant mode to Christian eschatology. ${ }^{16}$ Such a rapprochement between grief and faith is less tenable and more complex in the Lazarus plays.

Rosemary Woolf argues that the medieval English Lazarus plays shift the emphasis of the gospel narrative away from the miracle that reveals Jesus's divine nature to the problem of mourning the natural death of a family member. ${ }^{17}$ This focus upon the problem of death and the propriety of the sisters' mourning reveals an ideological preoccupation not found in the gospel's presentation of the climactic moment of Jesus's ministry: his command, 'Lazarus, come forth' (John 11:43). Woolf points out that all of the plays dwell on the problem of the sisters' grief, but this does not necessarily diminish the dramatic impact of Lazarus's miraculous return to life. In performance this moment has an iconic power that exceeds its textual framework. These opposing constructions of death and mourning coexist in dramatic tension. In medieval English drama, the scriptural story of Jesus's 
divine power over death is also the story of the death of a family member and how the two surviving sisters should grieve. The discursive practices of these plays seem aimed at transforming, or at least moderating, the social construction of mourning: turning the grief-stricken away from the practice of lament led by women towards the rituals of the church controlled by men. The sisters' central role in the plots of the Lazarus plays indicates the lingering authority of women over matters of death and mourning in medieval England.

The plays' ideological work is complicated by the fact that in scripture Jesus weeps with Mary Magdalene and her fellow mourners just before he raises Lazarus from the dead: 'When Jesus saw her [Mary] weeping, and the Jews who came with her also weeping, he was deeply moved in spirit and troubled; and he said, "Where have you laid him?" They said to him, "Lord, come and see." Jesus wept' (John 11:33-6). This moment gave rise to two opposing interpretive traditions: one that framed Jesus's display of sorrow as an endorsement of women's tears, and another that discredited this perspective. Early Christian and medieval exegetes interpreted this moment in different ways: as an example of Jesus's emotional restraint in the face of death; as a sign of his spiritual exertion while performing the miracle; or as an indication of his pity for non-believers.

Christine de Pizan uses the scriptural passage to argue against 'those who attack women for their habit of weeping'. She points out that Jesus was moved to compassion 'when he saw Mary Magdalene and her sister Martha weep for their dead brother', and asserts that their sorrow moved Jesus to resurrect Lazarus: 'What special favors has God bestowed on women because of their tears!'18 Her defense of female grief draws on a tradition of Christian thought that sees tears as expressions of compunction for $\sin .{ }^{19}$ Women were considered to be naturally more compassionate than men, and therefore more easily moved to Christian compunction and piety.

An opposing homiletic tradition censures female grief and mourning for the dead. These texts interpret Jesus's weeping as a gesture that signifies disapproval rather than empathy. Basil of Seleucia argues that Jesus wept in order to limit mourning by setting an example of restraint: 'He wept, He did not lament, or wail, or moan, or rend His garments, or tear His hair. ${ }^{20}$ In contrasting Jesus's simple weeping with ritual lamentation, the Bishop seeks to reform the mourning practices of his audience. Like the consolers of the $\mathrm{N}$-Town Lazarus who echo him, he argues that excessive weeping implies a lack of faith and offends God: 'Do not offend the One who has experienced the Resurrection by weeping immoderately' (180). He asserts that Jesus wept, not out of pity for Mary Magdalene or Lazarus but out of mercy for the 
'misguided views' of the Jews. A late Middle English sermon, dated sometime after 1490, like Basil of Seleucia's homily, shifts the meaning of Jesus's tears from sorrow to censure, stating that Jesus wept in order 'to make us undirstond how hard it is for anny man to ryse ageyn from synne when that he is fallen ther-in'. ${ }^{21}$ These interpretations efface the gospel's description of the sisters' grief, indicating that female mourning practices were a significant source of social friction.

The discursive maneuvers of the medieval English Lazarus plays, like those of the homiletic tradition, reveal cultural anxiety over the performance of female grief. Each of the Lazarus plays differs in its portrayals of mourning women, variations that are consistent with each cycle's central theological idea. David Mills notes the Chester's emphasis 'upon the fulfillment of divine purpose', the N-town's 'concentration upon grace', the York's illumination of 'human foible', and the Towneley's exploration of 'vital sin'. ${ }^{22}$ These distinct thematic emphases help to account for the differing ways each play treats the sisters' grief. The Chester Lazarus assimilates the sisters' ritual tears to prayer. Paradoxically, their feminine helplessness endows them with spiritual power: because they cry out for Jesus, he hears and answers their tears. The sisters' faith in Jesus drives the plot of the Chester play: when he responds to their prayerful laments, Jesus fulfills his divine purpose. In contrast, the $\mathrm{N}$-town, York, and Towneley versions depict the sisters' sorrow as excessive, contrary to faith, and offensive to God. In the N-Town, the male consolers praise Jesus's miracle as a gift of grace that the Magdalene, in her resistant and excessive mourning, never acknowledges. The York Lazarus casts mourning for the dead as the result of limited human perception, and therefore reveals the human foible of incorrectly interpreting the meaning of a dead body. The Towneley's stern focus upon sin is consistent with its negative portrayal of female grief. In this version Jesus reprimands Mary Magdalene for her spiritual weakness. Finally, the Digby play presents a stoic Mary Magdalene whose manly self-control marks her as a uniquely devout and heroic woman. This portrayal is in keeping with the genre of the play, and the aristocratic ethos of its heroine. Lawrence Clopper observes that 'the playwright wishes to present Mary as an apostle in her own right'. ${ }^{23}$ Because she is meant to be an exemplum of unwavering faith following her conversion, it is incumbent upon her to refrain from mourning the death of her only brother.

As in the homiletic tradition, the scriptural moment in which Jesus weeps appears to have presented a dilemma for the compilers of the medieval Lazarus plays. Each of them uses different strategies to distance Jesus from female grief and any association with mourning for the dead.. These divergent repre- 
sentations reflect Christ's different overall function in each cycle, which Alexandra Johnston succinctly identifies: 'In York he teaches; in Chester he acts; in Towneley he suffers; in N-Town he forgives. ${ }^{24}$ But when the plays are viewed synoptically, Jesus's tears emerge as a source of tension. In the York Lazarus Jesus teaches Martha and Mary Magdalene that grieving is sinful, and therefore refrains from weeping himself. In the Chester, he actively responds to their tears, and the moment at which he purportedly weeps is ambiguous. Two Jews, who are portrayed as evil and unreliable witnesses, comment upon his weeping, but nothing else, either in Jesus's words or the stage directions, indicates that he actually weeps. In the Towneley, Jesus weeps as he prays, implying that his tears are the result of his spiritual exertion. Here Jesus weeps, not in empathy with Mary Magdalene's sorrow, but instead because of the immense effort required to lift Lazarus out of his sinful state. In the N-Town, like the Chester, the moment is ambiguous. Jesus says that the weeping of the Magdalene and the Jews who are with her cause him to weep, but the Latin rubric has an odd distancing effect. It says 'hic ihesus fingit se lacrimari' [here Jesus pretends to weep] (between lines 372-3). Does the rubric mean to suggest that the real Jesus only pretended to weep, or that the person symbolizing Jesus is supposed to enact Jesus weeping? The second possibility is inconsistent with the text for presumably the other characters in the play are also 'pretending' to weep, yet no rubric designates this action. The first possibility is even more strange. Why would the real Jesus only pretend to weep? Does this mean to imply that because he is God and he knows there is no cause for sorrow, he cannot actually feel it, but as a human he feels compelled to display compassion? The uneasiness again manifests the play's ambivalence toward female grief. In the N-Town Lazarus, Mary Magdalene's grief is at once necessary and sinful: her tears impel Lazarus's resurrection, but Jesus's response to her (pretended or otherwise) denotes forgiveness rather than empathy.

The thematic differences among the cycles and the varying depictions of Christ's tears are no doubt also related to the regional historical development of each cycle, a question that merits further investigation. All of the extant Lazarus plays deviate markedly from John's gospel in ways that indicate considerable anxiety over the control of female mourning for the dead. Moreover, all of the plays are predicated upon the view that grieving is a gendered activity, and that mourning women are potentially helpless, immoderate, and in need of containment through prayer, privacy, and perhaps above all, masculine control. Yet the plays equivocate with this position, for in all of them female grief is integral to the unfolding dramatic action. The sisters' 
mourning, however denounced, curtailed, and eventually supplanted by Christ's divine power, is nevertheless a precondition for the performance of the miracle.

\section{The N-Town Lazarus}

The N-Town Raising of Lazarus enacts a gendered confrontation between the Christian doctrine espoused by four male consolers and the mourning ritual articulated by Martha and Mary Magdalene. Mary Magdalene's sorrow is characterized as excessive and troublesome, yet dramatically essential to Lazarus's resurrection. Her psychological and spiritual alignment with her brother drives the developing action, which unfolds in four episodes before Jesus arrives: Lazarus's death and the moments immediately following his demise; the funeral procession and burial; lamentation at the grave; and continued mourning after the interment. These four phases precisely correspond to the phases of mourning in the practice of ritual lament, a structure that also emphasizes the central conflict of the play. Each episode involves a dispute between Lazarus's sisters and four male 'consolers' over the propriety of grief. During each stage Martha and Mary Magdalene mourn violently in vivid gestures that evoke ritual lament: they tear their hair, wish for death, and throw themselves on the ground. Their exhibitions of sorrow draw sharp criticism from the male consolers. The men repeatedly attempt to curtail the sisters' laments, telling them that their weeping is pointless because death is both natural and unavoidable. The sisters respond by insisting upon their natural right and inherent obligation to grieve for their brother. Jesus's arrival moderates the discord between the consolers and the sisters, but because Mary Magdalene never acknowledges Jesus's power over death, the conflict is never completely resolved. This lack of resolution reinforces the gendered assumptions upon which the drama is based.

Throughout the play the Magdalene's entire being is aligned with Lazarus's condition. Just before he dies, she intuits his impending demise: 'Alas Alas what eylight me / myne herte for wo is wundyr grete' (55-6). Premonition is a characteristic feature of lamentation. Prophetic utterances embrace the belief that the woman's psyche is intimately connected to the life-cycle of the universe. Because women's cries were believed to influence this cycle, it was considered bad luck to mourn before death occurred. In a compelling rendering of this idea, Lazarus dies only a few lines after Mary Magdalene's exclamation of woe. This moment registers the threatening power of female 
mourning, for whether Mary Magdalene's grief intuits or accelerates her brother's demise, her sorrow is intimately tied to his destiny.

Immediately upon his death, the two sisters wail fervently, using gestures and motifs customary of lament. Mary Magdalene tears her hair: 'Alas ffor wo myn here I rende / Myn owyn dere brothyr lyth here now ded' (109-110). Martha's heart, like the body of her brother, and the earth that is its destiny, is 'colde as clay' (115). Mary Magdalene wishes to 'ly down by hym and dey' (124), for 'all joye is turnyd to woo' (128). These are familiar conceits from the genre of lamentation. Her desire for death elicits words of Christian consolation from the First Consoler: 'Be of good comforte and thank god of al / Ffor deth is dew to every man' (129-30). Martha responds, defending their laments, observing that mourning, like death, is natural and necessary: 'We all xul dye pat is sertan / but zit pe blood of kynde nature / Whan deth pe brothyr Awey hath $\tan /$ must nedys murne pat sepulture' (133-6). The Second Consoler admonishes them, urging them to proceed with the burial: 'holde zour pes / All zour wepynge may not amende itt / of lour sorwynge per fore now ses / And helpe he were buryed in a cley pitt' (137-40). This exchange clearly indicates the contrasting perspectives which are delineated by gender: the women articulate the residual view that their cries are both obligatory and necessary, while the men represent the Christian view that they are useless and therefore excessive.

The group processes to the grave: the men carrying the body and the women following behind 'with carefull herte' (152). The women lament throughout the procession and the burial. The Magdalene then attempts to remain at the grave to mourn after Lazarus is interred. From the viewpoint of ritual lament, the sisters' continual lamenting would have been efficacious, for their voices would have assisted the soul's journey, while providing cathartic relief for the community. From the Christian perspective, however, their voices are both excessive and offensive, because, as the consolers repeatedly tell them, their cries accomplish nothing, indicate doubt about the resurrection, and therefore offend God. The women's public display of grief elicits the most intense rebuke from the consolers. The Magdalene utters two more lines of lament before the consolers manage to remove her from her brother's tomb. As they do so, she declares: 'my brotherys graue lete me fyrst kys / Alas no whith may helpe my mon / Ffare wel my brothyr fare wel my blys' (178-80). In the genre of lament the mourner would bid farewell by kissing the corpse. Though she kisses the grave rather than the corpse, Mary Magdalene's gesture of farewell echoes this custom. The displacement of her kiss from the corpse to the grave suggests angst over portraying the actual 
gesture, which, as indicated by the ecclesiastical record from Lancaster, prevailed into the late sixteenth-century. Her lyric good-bye elicits further censure from the Third Consoler: 'In dede ze do ryght sore amys / so sore to wepe as 1e do here' (183-4). The sisters' behavior at Lazarus's tomb moves the consolers to their most severe reproofs. The consolers seem to object most to the ritualistic implications of the sisters' public performance of grief, for they tell the sisters to return to the privacy of their home to mourn and agree to stay and comfort them.

In her home the Magdalene denies social interaction in a characteristic gesture of continued mourning and communion with the dead. When Jesus arrives she says that he has come too late, rejecting the consolers' admonishments to cease her mourning. Martha turns to Jesus, expressing her faith in him, but the Magdalene remains disconsolate: 'Alas my mowth is bytter as galle / grett sorwyn my herte on tweyn hath scorn / Now pat my brothyr from syth is lorn / per may no myrth my care releve / Alas pe tyme pat I was born / pe swerde of sorwe myn hert doth cleve' (323-8). Her use of the motif of the 'sword of sorrow' alludes to the sorrow of the Virgin Mary. In fulfillment of Simeon's prophecy in Luke 2:34-5 Mary experiences piercing agony during Christ's passion. However, this analogy between the Magdalene's and the Virgin's grief seems precarious because the play strongly suggests that the Magdalene's mourning puts her in a state of sin.

The play extends this unstable analogy between the Magdalene and the Virgin. In the N-Town Passion, the Virgin's mourning and Christ's suffering are intertwined. After Christ's burial, Mary weeps in the temple, and as she does, Christ harrows Hell and then rises again. This simultaneous staging invests Mary's tears with dramatic agency, showing her full participation through her mourning - in the salvation of the world. Similarly, in the N-Town Lazarus, the Magdalene's choices seem to drive her brother's destiny. Her return to the community from the isolation of her grief prefigures Lazarus's return from the grave: a poetic echo indicates this connection between the Magdalene's dolor and recovery and Lazarus's death and resurrection. When Jesus asks for the Magdalene, Martha calls to her: 'Sustyr magdalen com out of halle' (337, emphasis added). Jesus echoes this call when he invokes Lazarus to rise: 'Ffrom pat depe pitt come out a-non' (422, emphasis added). The word 'halle', while designating the living space of medieval homes, also sounds very much like the word 'hell'. The implications of this assonance is reinforced by Jesus's call to Lazarus to come out of the 'depe pitt', a common epithet for hell. In other words, the Magdalene must first emerge from the sin of her mourning before Lazarus can be raised by Jesus from the 
hell of death. Again and again in this play, the Magdalene's sorrow and Lazarus's destiny are intertwined. The play expands upon the gospel account in order to emphasize the excessive nature of the Magdalene's mourning even as that excess compels the action.

Moreover, the play intensifies the focus upon the Magdalene's grief by dilating simple narrative references in John into moments of high drama. In scripture, John simply states: 'When the Jews who were with her in the house, consoling her, saw Mary rise quickly and go out, they followed her, supposing that she was going to the tomb to weep there' (John 11:31). In the N-Town play, the Third and Fourth Consolers exchange excited comments on her behavior. The Third Consoler exclaims, 'Herke gode ffrendys I zow pray / Aftyr pis woman in hast we wende / I am a-ferde ryght in good fay / here-self for sorwe pat she wyl shende' (345-8). The Fourth Consoler agrees, 'Here brothyr so sore is in hire mende / She may not ete drynke nor slepe / streyte to his graue she goth on ende / As a mad woman per for to wepe' (349-52). Another telling augmentation of the gospel is the moment of Jesus's arrival, which in the N-town becomes another opportunity for portraying the Magdalene's grief as excessive and troublesome. Whereas in John Mary Magdalene goes to Jesus as soon as Martha calls her, in the $\mathrm{N}$-town play, she responds bitterly to her sister's summons (341), and goes to him reluctantly: 'me thynkyth longe or I come thedyr' (344). She greets Jesus with the familiar biblical line that he could have prevented Lazarus's death if only he had been present (353-6). ${ }^{25}$ However, her ensuing lament seems to challenge his healing power, because she asserts that nothing can conquer death: 'Ageyn deth is no resystens / Alas myn hert is woundyrly wo / Whan pat I thynke of his Absens / pat ze zour-self in herte lovyd so' (357-60). These embellishments of scripture characterize Mary Magdalene as excessive in her sorrow and deepen the implication that her grief is sinful, but they also make her mourning central to the play's architecture.

Jesus's arrival reconciles the opposition between the consolers and the sisters, creating a community of mourners for the first time in the play. In his presence, the consolers express their sorrow. The First Consoler confesses that 'pe losse of hym doth marre oure mood' (364). The Second Consoler echoes him in a lilting lyric: 'now he is gon, gon is oure frende' (368). This chorus of grief compels Jesus to weep: 'I can not me for wo restreyn / but I must wepe lyke as ze do' (371-2). Jesus's expression of sorrow, however, does not sanction Mary Magdalene's mourning, and the tension between her role as mourner and Jesus's role as redeemer is never resolved. The Magdalene, whose grief forms the dramatic premise for Jesus's miracle, never acknowledges 
Jesus's power over death, even after Lazarus rises from the tomb. At the end of the play the consolers join in a choric refrain that noticeably excludes the voices of the women. Together the consolers proclaim their faith in Jesus as the conqueror over death: 'O sovereyn lord of most excellens / helpe vs of zour grace whan pat we go hens / Ffor azens deth us helpyht not to stryve / but azen zoure myght is no resistens / oure deth ze may A-slake and kepe vs stylle on lyve' (444-8). This echo of Mary Magdalene's earlier words, 'Ageyen deth is no resystens' (357), emphasizes her marked absence from the concluding hymn of praise. The characterization of Mary Magdalene's sorrow as excessive and sinful thus reinforces the gendered assumption that women are more prone to grief than men, and therefore in need of masculine guidance and control in times of sorrow.

Despite the consolers' reproofs, the sisters, and especially Mary Magdalene, manage to perform virtually all the stages and gestures of ritual lament before Jesus arrives. The evidence from the Lancastrian record describing the coexistence of catholic burial and ritual lament indicates that the portrayal of mourning and burial in the N-Town Lazarus corresponds fairly accurately to actual practice. Anthropologists have long observed that when it comes to matters of burial, cultural beliefs and practices are extremely conservative and resistant to change. As the N-Town Lazarus demonstrates, the denounced and excessive female lamenter performs important cultural work. She ensures that the dead are mourned, commemorated, and remembered in the community, even as she is ostracized for doing so.

\section{The York Lazarus}

Whereas in the N-Town Lazarus, Mary Magdalene's mourning is both dramatically necessary and yet resistant to the play's teleology, the York Lazarus achieves closure through Mary Magdalene's dramatic repudiation of her inconsolable grief. The play uses a commonplace of women's lament - the mourner's cry of anguish as she gazes upon the dead body - to demonstrate that Christ's miracle alters human perception even as it heals unforgettable grief. The drama defines Lazarus's dead body as signifier, enacting a ritual transformation of its meaning. First interpreted by Maria as an emblem of unending pain, Lazarus's body accrues new meaning for those who see and believe in Jesus's miracle.

Early in the play Jesus declares to his apostles that he will go to Bethany to cure the sisters of their sorrow, explicitly linking the necessity of his miracle to their mourning behavior: 'His sisteres praye with bowsom beede / And for 
comforte pei call and craue, / Therfore go we togedir / To make pere myrthis more' (141-4). Jesus describes the sisters' mourning as a form of prayer, but their cries have no Christian sentiments: they are grounded in the ethos of inconsolable grief and the motifs of lament. Jesus's reference to the rosaries the sister's presumably hold as they wail shows once again how ritual lament seems to have coexisted with Christian practices. But the juxtaposition of lament with prayer creates a dissonance that the action of the play attempts to resolve. As the plot unfolds, it enacts the displacement of the ethos of unforgettable sorrow with the Christian promise of eternal life.

The action develops in a sequence of rhetorical forms that shape the play's discursive design: the sister's laments are superseded first by Jesus's prayer, then Lazarus's exhortation, and finally Jesus's blessing as the sanctioned interpretations of the meaning of Lazarus's body. The act of seeing, a reference both to the character's perception of the corpse and the audience's experience of the action on stage, forms the premise of each character's address. The sisters' profound sorrow drives the plot of the play as Maria cries out in despair and Martha searches for Jesus to help them.

Maria's lament articulates her ritual perception of Lazarus's body as a lifeless corpse, a gaze that embodies unending pain: 'Allas owtane Goddis will allone, I Pat I schulld sitte to see pis sight / For I may morne and make my mone, / So wo in worlde was neuere wight. / Pat I loued most is fro me gone, / My dere brothir pat Lazar hight / And I durst saye I wolde be slone / For nowe me fayles both mynde and myght' (147-54). She ends her lament, transfixed by Lazarus's dead body, insisting upon her inconsolable grief and desire to join him: 'My welthe is wente for euere, / No medycyne mende me may. / A, dede, pou do thy deuer / And haue me hense away' (155-8). Apart from being a beautiful alliterative lyric, this twelve-line lament possesses many of the characteristics of ritual lament. The opening of the lyric establishes the importance of the mourner's gaze on the body: her lament will interpret and articulate the meaning of death. She establishes her right to mourn by announcing that she weeps for her brother, Lazarus. She proclaims her grief as unending and more severe than anyone's. Finally, she wishes to die in order to preclude separation from her brother. Despite what Jesus says, Maria does not pray; she mourns. Moreover, with her opening line she directly cries out against God's will that her only brother should die: 'Allas, owtane Goddis will allone' (147). The resistant stance of her lament heightens the emotional drama of these lyric exchanges. In ritual lament, the mourner addresses the corpse, asking the deceased why he has abandoned the mourner. In the play, this rhetorical gesture is transferred from the corpse to God as Maria cries out 
in the extremity of her grief. This shift suggests, as in the book of Job, God hears and answers those who cry out to him, even when they do so in anger.

Whereas Maria denies that she will ever be cured of her sorrow, Martha begins with ritual lament, but midway through she turns away from her brother's dead body towards Jesus. Like Maria, she begins by expressing inconsolable grief and a desire for death: 'Allas, for ruthe now may I raue / And febilly fare by frith and felde, / Wolde God pat I wer grathed in graue, / Pat dede hadde tane me vndir telde. / For hele in harte mon I neuere haue' (159-63). However, at the midpoint of her lament, she turns to Jesus for comfort: 'But if he helpe pat all may welde, / Of Crist I will som comforte craue / For he may be my bote and belde' (164-6). She resolves not to cease looking 'Tille I my souereyne see' (168), thus shifting her gaze from her brother's lifeless body to her lord's incarnate one. Martha's change prefigures her sister's. Unfortunately, the precise details of Maria's exchange with Jesus are a mystery because nearly four complete stanzas are missing from the manuscript at this point. The missing elements are Jesus's arrival at Bethany and his exchanges with each sister. The manuscript resumes with the removal of the stone from Lazarus's grave and Jesus's supplication to God.

When Jesus prays to God, asking him to return Lazarus to life, he echoes Maria's cry of agony, calling attention to the new meaning his miracle bestows upon the dead body. Maria's wail directs the audience to experience the grief and disorder of death through her suffering gaze: 'pat I schulld sitte to see pis sight' (148). In contrast, Christ avows that those who see his miracle, 'Pat standis and bidis to se pat sight' (180), will know that God has sent him. Similarly, when Lazarus emerges from the tomb, he designates his body as a sign, not of death, as in Maria's vision, but of God's power. The event, he declares, 'pus hast schewed pi myght in me' (188). In yet another reference to vision and perception, Lazarus urges the audience to see that Christ's miracle denotes his incarnate deity and bestows salvation upon the faithful. Those who believe will not see a corpse, but instead a vision of eternal life: 'By certayne singnes here may men see / How pat pou art Goddis sone verray. / All po pat trulye trastis in pe / Schall neuere dye, pis dar I saye' (190-3). This sequence of speeches redefines the meaning of death, replacing the ritual imprint of inconsolable grief with the Christian belief in redemption and eternal life.

Even as it displaces Maria's sorrowing gaze with Christ's spectacle of joy, however, the York Lazarus pays tribute to the authorial voice of women's laments. For just as Maria's gaze initially guides the audience to see Lazarus's death as torment, the play's closure depends upon her affirmation to redirect 
the audience's sight to Christ: 'Here may men fynde a faythfull frende / Pat pus has couered vs of oure care' (198-9). In a final echo of the 'sight' of her opening lament, Jesus, empowered by Maria's transformation, reminds the audience, '3e pat haue sene pis sight / My blissyng with zo be' (208-9).

Supplanting Maria's ritual lament by Jesus's raising of the dead, the York play re-inscribes the ethos of inconsolable grief as a sign of disbelief and excessive sorrow. Those who trust in Christ will not see a corpse when they look upon the dead; they will see the promise of Christ's blessing: redemption and eternal life. Yet, because the sisters' laments drive the action, the play's dramatic closure rests upon a paradox. Jesus's blessing upon the audience for 'seeing' (as in 208-9 cited above) raises the question of what exactly they have just seen. They have witnessed not only the miraculous raising of Lazarus, but also the insistent grief of mourning women, grief with the power to beckon the Son of God himself.

\section{The Chester Lazarus}

As we have seen, the York play rewrites the ethos of mourning through the poetic repetition and transformation of a conventional ritual motif of lament. The Chester Lazarus, in contrast, assimilates the sisters' mourning ritual to prayer. As in the N-Town and York cycles, the sisters' grief structures the action of the Chester play, which begins with the sisters' cries of woe and ends with their lyrics of joy. This framing of the play by the sisters' sorrow and subsequent joy demonstrates how essential their voices are to the legitimacy of its ideological message. For, as in the York Lazarus, the Chester's dramatic closure depends upon the sisters' concluding testimonials to Jesus's power. As in the N-Town Lazarus, the sisters mourn at Lazarus's tomb, a clear departure from John's gospel account that reveals the play's concern with the propriety of female grief. Yet, in contrast to the $\mathrm{N}$-town and the York versions, which oppose mourning to Christian faith, the Chester play aligns them. In this version, the sisters do not need to be taught the meaning of eternal life (as in the gospel account and in the other cycles), they already know and believe. Their ritual at Lazarus's tomb becomes an ideal act of Christian piety: they are not mourning for their dead brother, they are supplicating Jesus with their prayerful tears.

The play opens with Maria crying for Jesus: 'A lord Jesu, that me is woo / to wytt my brother syckly soo! / In feeble tyme Christ yoode me froo' (301-3). While punctuated with the traditional sighs of 'A' and 'Alas', the Chester sisters' cries denote Christian helplessness and faith, rather than rites of lament. Following Maria's opening lament, the play departs from scripture, 
as Martha herself seeks out Jesus instead of sending a messenger: 'Yea, sister, abowt I will goe / and seeke Jesu too and froo' (305-6). Placing the women firmly at the center of the dramatic action, this alteration also creates the opportunity for an exchange between Martha and Jesus in which he tells her that he is God's son and 'that sickenes is not deadly' (314). Martha seems to understand Jesus's elliptical language. When she returns home, she finds Maria in the throes of grief: 'A, Martha, sister, alas, alas! / My brother ys dead syth thou heere was. / Had Jesus my lord binne in this, / this case had not befalne' (317-20). Martha has returned home to find an apparent contradiction: Jesus promised that her brother's illness was not fatal. Yet she already knows that he can raise the dead: 'Yea, sister, neare is Godes grace. / Manye a man hee holpen hasse. / Yett may hee doe for us in this case / and him to life call' (321-4). The two sisters decide to mourn at their brother's tomb as a means of invoking Jesus's aid.

As in the N-Town, the scene at Lazarus's burial site vividly evokes residual lament as the sisters enact a tearful vigil. They sit on the ground in postures of extreme grief, their language indicating the ritualized nature of their sorrow. Maria declares, 'Here will I sitt and mourninge make / tyll that Jesu my sorrowe slake. / My teene to harte, lord, thou take, / and leech mee of my woe' (325-8) Maria does not simply feel sorrow, she 'makes' mourning. Similarly, Martha declares: 'In sorrowe and woe here wyll I wake, / and lament for Lazar my brothers sake. / Though I for coulde and pennance quake, / heathen will I not goe' (329-32). The sisters are not merely expressing feelings; they are performing a ritual, for they declare they will remain at the tomb, despite personal discomfort, until they achieve clearly articulated ends: Maria will mourn until Jesus comes to cure her, and Martha will 'wake' for her brother's benefit. Their ritual objectives show that they believe their cries will be heard and answered by Jesus.

The scene's staging reinforces the implicit power of their cries, for the Latin rubric suggests that the sisters' ritual weeping and Jesus's decision to go to them occur simultaneously: 'Tunc pariter juxta sepulchrum sedebunt plorantes, et Jesus procul sit [Then they, the weepers, sit together near the tomb and Jesus is at a distance]' (between lines 332-3). Although they were understood to be separated by several days' travel, the stage direction indicates that the sisters and Jesus are on stage at the same time. The visual telescoping of space and time indicates that the sisters' mourning ritual has invoked divine will: Jesus seems to have been mysteriously beckoned by their tears when he declares to his disciples: 'Brethren, Goe we to Judye' (333). 
Because Martha already knows that Jesus has the power to raise the dead, the sisters' ritual at their brother's grave is aligned with Christian teleology. Their wails are depicted as fervent supplications heard and answered by Christ, rather than ritual laments with the power to awaken the dead. Moreover, as in the N-Town Lazarus, the iconography of the sisters lamenting at a sepulchre creates a typological association with the laments of the three Maries in the Resurrection sequence. Echoing Christine de Pizan's defense of female woe, the Chester play consecrates the ability of women's helpless tears to commune with God.

Jesus hears and answers their laments. When he arrives at their home in Bethany, each sister lyrically addresses him in turn. Their respective dialogues with Jesus follow scripture, which develops the theological concept that resurrection and grace depend upon faith in God. Although they do not fully perceive the extent of Jesus's power, they have complete faith in his teachings, which each dutifully recites at his bidding. Martha tells him that she steadfastly believes that he is God's son and asks him to have mercy on her and her sister (394-400). When Maria enters, she simultaneously professes sorrow and steadfast belief 'A, lord Jesu, haddest thou binne here, / Lazarre my brother, thy owne deare / had not binne dead in this manere. / Mych sorrowe is me upon' (418-21). At the point where Jesus purportedly weeps, the rubric refers to the entrance of two Jews, mentioning nothing about Jesus's tears. ${ }^{26}$ In the absence of a rubric or clear stage direction, the only indication that Jesus weeps comes from the bitter words of the First Jew as Jesus approaches Lazarus's tomb: 'See fellowe, for cockes soule, / this freake beginneth to reeme and yowle / and make great dowle for gowle / that hee loved well before' (426-9). The First Jew's remark differs markedly in tone and purpose from the scriptural account: 'So the Jews said, "See how he loved him!'” (John 11:36). Because the Chester play aligns weeping and prayer, the exaggerated response of the Jews may indicate their stereotypical association with hearts of stone. In this case, the Chester seems to defend weeping for the dead, as long as that weeping occurs within the framework of faith. Like the sisters in the play, the mourner must turn to Jesus in her sorrow: The portrayal of Jesus in the Chester cycle thus affirms moderate grief, as long as it is expressed within the ritual structure of Christianity.

When Lazarus emerges from the tomb at Jesus's command, he presents to the audience the allegorical meaning of the miracle. He praises his lord for freeing him from sin and death: 'Lord, when I hard the voyce of thee, / all hell fayled of there postie, / so fast from them my soule can flee; / all divells were afrayd' (454-7). In scripture Lazarus goes silently on his way (John: 11: 
44). The Chester play, in contrast, shifts the dramatic focus back to the two sisters. They affirm Jesus's power with hymns of joy, drawing attention to the fact that their grief has compelled the play's dramatic movement. Martha sings a hymn of praise, emphasizing that Jesus has saved them 'from mych woe' (460). Maria's hymn is twice as long. She begins by echoing her sister's sentiment that Jesus has cured them of grief: 'for nowe my harte is glad and light / to see my brother ryse in my sight' (467-8). In the second stanza, she assumes the traditional role of the lament-poet; her personal testimony inscribes the meaning of the miracle onto the communal memory: 'By verey signe nowe men maye see / that thou arte Godes Sonne' (476-7). The Chester Lazarus thus constructs female grief as powerful when it is perfectly aligned with Christian faith. Because the sisters never doubt Jesus's power, he responds to their tearful prayers and fulfills his destiny. This version of the Lazarus miracle thus reconciles ritual lament with Christian doctrine by assimilating the ritual of grief to the exertions of prayer.

The Chester play demonstrates how residual lament and Catholic doctrine coexisted. There is a compelling analogy here between the sisters' belief that their tears are spiritually efficacious and Margery Kempe's gift of tears. During the Easter vigil Margery would weep for hours on end for the souls in purgatory, believing that her tears helped to release them from their suffering. ${ }^{27}$ Since the ultimate message of the Chester Raising of Lazarus is that faith in Jesus leads to salvation and triumph over death, the agency of the sisters' tears is assimilated to and contained within Christian eschatology. But the centrality of the sisters' grief to the dramatic structure of the play resists this accommodation.

\section{The Towneley Lazarus}

The Towneley Lazarus differs significantly from the N-Town, York, and Chester in subject matter and theme. Whereas the other three plays stress Jesus's love and pity for suffering humankind, the Towneley play emphasizes God's exacting judgement, the need for unwavering faith, and personal accountability. It highlights the importance of spiritual autonomy over reciprocal communal empathy.

The Chester play opens with Martha and Mary Magdalene's cries, and in the York and N-Town, Jesus specifically links his decision to go to Bethany to the sisters' laments. In contrast, the Towneley play passes over this connection. Instead, it emphasizes Jesus's supernatural knowledge by opening with his announcement to the disciples that he knows Lazarus has died. The 
play also departs from scripture in characterizing Mary Magdalene's grief as a sign of weakness bordering on sinful despair. This depiction is in keeping with the play's stark mood and dramatic theme: 'that God releases the faithful from bondage'. ${ }^{28}$ The play insists that the only secure means of salvation is through faith in Christ. In the stern homily Lazarus delivers from the edge of his tomb, he cautions the audience against reliance upon the goodwill of others to save them from the torments of hell. While diminishing the roles of the sisters relative to the other plays, the Towneley play nevertheless associates Mary Magdalene's grief with Lazarus's death and resurrection. As in the N-Town play, the Townley Lazarus casts Mary Magdalene's grief as a form of confinement from which she must be released, just as Lazarus must be freed from the captivity of death. In the N-Town, however, Mary Magdalene's choice to emerge from her mourning invests her with agency - it is her will that is a precondition for Lazarus's resurrection. In the Towneley Lazarus Jesus must free Mary Magdalene from her sorrow before he frees Lazarus from the bondage of sin and death.

Even though the Towneley play minimizes the agency of female grief, it still links Mary Magdalene's emotional state with Lazarus. Lazarus's exhortation on death reinforces the message that mourning for the dead is sinful. Echoing Luke's parable of Lazarus and the rich man, it aligns his return from the grave with Christ's harrowing of hell and the call of God's trumpet on the day of the last judgment. When Martha tells Mary Magdalene that Jesus has come, her words suggest that her sister's mourning is a form of bondage: 'Sister, lefe this sorowful bande' (63); in John's account, Martha simply says, 'The Teacher is here and is calling for you' (11:28). ${ }^{29}$ Moreover, in the scriptural account, Mary Magdalene runs to Jesus without hesitation: 'And when she heard it, she rose quickly and went to him' (11:29). The Towneley play presents her emotional state in a more negative light. Here, Mary Magdalene exclaims, 'A, for godys luf let me go!' (66), as if she is struggling to extricate herself from unseen chains. The repetition of 'bande' makes explicit the association of Mary Magdalene's release from grief and Lazarus's release from death. After Jesus commands, 'Com furth, lazare, and stand vs by' (97), he directs, 'Take and lawse hym foote and hande, / And from his throte take the bande' (99-100). It is not clear whom he addresses with the instructions to strip Lazarus of his grave clothes. Presumably it is the sisters, for they are the only others on stage.

By stressing that Mary Magdalene's sorrow, like death itself, is a form of bondage from which only faith in Jesus can free her, the Towneley Lazarus suggests that her grief is sinful. Jesus reinforces this meaning in his unbiblically 
austere response to her anguish. Twice the Towneley Jesus deviates from scripture and implies that Mary Magdalene's feelings show spiritual frailty. The first time occurs when Mary Magdalene greets Jesus with a description of her sorrow drawn from a familiar motif of ritual lament: 'mekill sorow may men se / Of my sister here and me: / We are heuy as any lede, / ffor our broder that thus is dede' (69-72). Her melancholy elicits a stern warning from Jesus, who cautions her: 'Bot loke no fayntyse ne no slawth / Bryng you oute of stedfast trawthe' (77-8). The Magdalene's sorrow elicits not compassion, as in John, but censure; Jesus implies that her emotion borders on despair. Prior to this moment Jesus has used the word 'fayn' twice: first in assuring Martha that she 'may be fayn [joyful]' (43) because her 'brothere shall rise and lif agayn', (44), and next because he [Jesus] has come to help them: 'Go tell thi sister mawdlayn / That I com, ye may be fayn' (61-2). The repetition of the word and its antonym indicates that Mary Magdalene's behavior directly opposes the appropriate Christian response, both to Jesus's arrival and to Lazarus's death.

The Towneley version also subtly emends the biblical account of Jesus's weeping, just enough to eliminate any affinity between Mary Magdalene’s and Jesus's tears. The Towneley rubric, 'Et lacrimatus est Jhesus, dicens', comes just before Jesus utters the words: 'ffader, I pray the that thou rase / lazare that was thi hyne, / And bryng hym oute of his mysese / And oute of hell pyne' (89-92)..$^{30}$ This conflation of weeping with prayer signifies, as Riemer argues, the intensity of Jesus's supplication rather than empathy for the bereaved sisters. ${ }^{31}$

Upon emerging from the tomb Lazarus addresses the audience with a memento mori sermon. ${ }^{32}$ Throughout the address, Jesus, Martha, and Mary Magdalene remain on the stage. As Barabara I. Gusick points out, this presence is 'an uncomfortable fit' (34). The exhortation's stark and frightening message conflicts with a biblical story that originally encompassed both communal empathy and the need for personal faith. The Towneley Jesus is directive and stern rather than loving and compassionate. Given the presence of his sisters on stage next to Jesus, Lazarus's warning to the audience that the family's 'sorow' will 'slake' (157) is especially discordant. Mary Magdalene did not cease sorrowing: Jesus made her stop. The Towneley Lazarus thus condemns female mourning to such an extent that it subverts its own dramatic and theological coherence. Dramatically, as Gusick's remark indicates, this condemnation is incongruous with the staging of the play. Theologically, the play's message contradicts that of John's gospel which presents a compassionate and forgiving Jesus who moderates rather than denounces grief. 


\section{The Digby Mary Magdalene}

Although the Lazarus episode in the Digby Mary Magdalene differs markedly from the Towneley in its characterization of the Magdalene, it embodies similar disapproval towards mourning for the dead. Lazarus's death is one among many episodes in this epic Saint's play that follows the life of Mary Magdalene from her worldly aristocratic adolescence in her father's kingdom (Jerusalem, Bethany, and the Castle of Magdala), through her waywardness and sin, to her ultimate sanctification and saintly performance of miracles. It is likely that the genre of this play, and its portrayal of Mary Magdalene as an aristocrat influence the characterization of her grief. Significantly, early in the play when her father Cyrus dies, it is Mary Magdalene's inordinate mourning for his death that makes her vulnerable to lechery, the first of the seven deadly sins to overtake her. ${ }^{33}$ Thus, later in the play, Mary Magdalene's stoic response to her brother's death demonstrates her transformation and new found elevated spirituality. Both sisters in the Digby play are less passionate in their grief than in the cycle plays. This stoicism reflects their social status; as aristocrats, they can afford to hire mourners rather than engage in the dirty work of mourning themselves. Mary is depicted as even less emotional than Martha. When her brother dies, she expresses unwavering faith rather than grief: 'Jhesu, my Lord, be yower sokowre, / And he mott be yower gostys welth!' (824-5). Martha responds, referring to their obligation to bury rather than to mourn their brother as in the cycle plays: 'We must nedys ower devyrs doo, / To pe erth to bryng wythowt delay' (832-3). Unlike the sisters of the other plays, these sisters waste no time with waking and wailing. All business, they immediately arrange for Lazarus's burial. These conspicuously aristocratic and dispassionate ladies contrast sharply with the mourning women of the cycle plays. The Magdalene refrains from weeping herself, but nevertheless honors 'custom' by ordering her knights to hire black-clad weepers for her brother Lazarus's funeral: 'As pe vse is now, and hath byn aye, / Wyth wepers to pe erth yow hym bryng. / Alle pis must be donne as I yow saye, / Clad in blake, wythowtyn lesyng' (834-7). This particular line is also further evidence of residual social practice, for we find the heroine of the play telling us that it is the 'custom' to have 'weepers' accompany funeral processions. The Magdalene's self-conscious appeal to 'custom' as justification for her brother's funeral rite also points to an inherent dichotomy between her personal adherence to Christian doctrine and her public accommodation of residual practice, further implying a hierarchy of values. For her stoic response underwrites her heroism and sustains the hagiographic integrity of the play. This impassive Lady Magdalene displaces 
her grief onto the emblematically somber procession that carries her brother's corpse to the grave, foreshadowing Post-Reformation England's aesthetic enshrinement of female mourning. ${ }^{34}$

\section{Conclusion}

The medieval English Lazarus plays attempt to resolve the inherent opposition between the residual practice of lament and the dominant Christian eschatology, redirecting and containing the potentially subversive ethos of this construction of female grief. The N-Town and Towneley plays construct mourning as a form of confinement, akin to sin, from which Christian faith provides release. The York play similarly acknowledges the centrality of the sisters' mourning, even as it re-inscribes their grief as excessive and contrary to faith. In contrast, the Chester version characterizes the sisters as models of Christian humility, whose helplessness paradoxically endows them with the power to summon the son of God himself. Perhaps the most ambivalent representation of female grief, however, is in the characterization of the heroine of the Digby Mary Magdalene as tearless and firm in the face of her only brother's death. As an aristocratic heroine, this stoic lady claims her superior social and spiritual status by not weeping. Instead, she acquiesces to the custom of hiring weepers to carry Lazarus to the grave, a practice that she places herself above.

As the plays attempt to assimilate residual mourning practices to Christian eschatology, they also perform resistance to that teleology. The intensity of the sisters' grief for their brother must have resonated with medieval audiences who faced so many deaths of loved ones during their brief lives. On the one hand the cultural work done by these plays reinforces the gendered assumption that women are naturally more prone to excessive sorrow than men, and that grief itself is an excessive, feminine emotion. On the other hand, they acknowledge the resistant power of female grief, constructing it upon the underlying paradox that women's tears are not only excessive and subversive, but also necessary and efficacious.

\section{Notes}

1 I am grateful to the anonymous readers of Early Theatre for their insights. Lisa Perfetti and the reader at Florida University Press also made also made helpful suggestions. Jennifer Vaught made editorial comments on an early draft. Lisa 
Carp assisted with research and proofing. Finally, I am thankful for the 'Medieval Mondays' group at Purdue University, and especially Ann Astell who encouraged me to present this argument as a paper at their gathering.

2 Citations of the N-Town cycle are from Ludus Coventriae or The Play Called Corpus Christi, K.S. Block (ed), Early English Text Society (Oxford, 1922; rpt 1974). Citations from the York cycle are from The York Plays, Richard Beadle (ed) (London, 1982). Citations of the Chester cycle are from The Chester Mystery Cycle, R.M. Lumiansky and David Mills (eds), Early English Text Society (Oxford, 1974). All references to the commentary or glossary of the Chester cycle are from The Chester Mystery Cycle: Volume II, Commentary and Glossary, R.M. Lumiansky and David Mills (eds), Early English Text Society (Oxford, 1986). Citations of the Towneley cycle are from The Towneley Plays, George England and Alfred Pollard (eds), Early English Text Society (London, 1897). Citations of the Digby Mary Magdalen are from The Late Medieval Religious Plays of Bodleian MSS Digby 133 and Museo 160, Donald Baker, John Murphy, and Louis Hall (eds), Early English Text Society (Oxford, 1982), 24-95.

3 Margaret Alexiou, The Ritual Lament in Greek Tradition (Cambridge, 1974, rpt 2002); Mary Agnes Doyle, 'Games of Lamentation: The Irish Wake Performance Tradition', PhD thesis (Northwestern University, 1988); Gail Holst-Warhoft, Dangerous Voices: Women's Laments and Greek Literature (London, 1992).

4 Peter Dronke, 'Laments of the Maries: From the Beginnings to the Mystery Plays', Idee, Gestalt, Geschichte: Festschrift Fur Klaus von See, Studien zur europpäischen Kulturtradition, Gerd Wolfgang Weber (ed) (Odense, 1988), 89-116 at 103-4.

5 See Adena Rosmarin, The Power of Genre (Minneapolis, 1985), 50.

6 See Nikolai Kaufman, 'Laments from Four Continents: Europe, Asia Africa, and America', International Folklore Review 7 (1990), 22-9; Tauno F. Mustanoja, 'Beowulf and the Tradition of Ritual Lamentation', Neuphilologische Mitteilungen LXVII (1967): 2-27.

7 See Margaret Alexiou, Ritual Lament. Mary Agnes Doyle, 'Games of Lamentation'; Angela Bourke, 'More in Anger than in Sorrow: Irish Women's Lament Poetry', in Feminist Messages: Coding in Women's Folk Culture (Urbana, 1993), 165-8; Angela Bourke, 'The Irish Traditional Lament and the Grieving Process', Women's Studies International Forum 11 (1988): 287; Tauno F. Mustanoja, 'The Unnamed Woman's Song'; Gail Holst-Warhoft, Dangerous Voices; Sharon T. Strocchia, Death and Ritual in Renaissance Florence (Balti- 
more, 1992); Bade Ajuwon, 'Lament for the Dead' as a Universal Folk Tradition', Fabula 22 (1981): 272-80; Kaufman, 'Laments from Four Continents'; Nancy Sultan, 'Private Speech, Public Pain: the Power of Women's Laments in Ancient Greek Poetry and Tragedy', Rediscovering the Muses: Women's Musical Traditions, Kimberly Marshall (ed) (Boston, 1993), 92-110; Gary A. Anderson, A Time to Mourn, A Time to Dance: The Expression of Grief and Joy in Israelite Religion (University Park, PA, 1991).

8 For a study of laments for the dead in medieval English literature see Velma Bourgeois Richmond, Laments for the Dead in Medieval Narrative (Pittsburgh, 1966) and Renate Hass, 'The Laments for the Dead', The Alliterative Morte Arthure: A Reassessment of the Poem, Karl Heinz Goller (ed) (Cambridge, 1981), 117-91.

9 Matthew Parker, A Funerall Sermon ... Preached at S. Maries in Cambridge, Anno 1551, at the buriall of. . Martin Bucer, trans Thomas Newton (London 1587); cited in G.W. Pigman, Grief and the English Renaissance Elegy (Cambridge, 1985), 30 .

10 Hugh Latimer, Certayn godly Sermons, made uppon the lords Prayer (London, 1562), 230-1; cited in Pigman, Grief, 32.

11 Thomas Becon, The Sicke Mannes Salve, in Prayers and Other Pieces of Thomas Becon, John Ayre (ed) (Cambridge, 1846), 88-91.

12 Anon., The Preparacyon to the Crosse with the Preparcyon to deeth (London, approx. 1545), N5v; cited in Patricia Phillippy, Women, Death and Mourning in Post-Reformation England (Cambridge, 2002), 25.

13 F.R. Raines (ed), A Description of the State, Civil and Ecclesiastical, of the County of Lancaster about the Year 1580 (Manchester, 1875), 5-7; cited in David Cressy, Birth, Marriage, and Death: Ritual, Religion and the Life-cycle in Tudor and Stuart England (Oxford, 1997), 400.

14 The Alliterative Morte Arthure: A Critical Edition, Valerie Krishna (ed) (New York, 1976), lines 4328-41.

15 For an explication of this pedagogy see George R. Keiser, 'The Middle English Plantcus Mariae and the Rhetoric of Pathos', in The Popular Literature of Medieval England, Thomas J. Heffernan (ed), Vol 28: Tennessee Studies in Literature (Knoxville, 1985); see also Eamon Duffy, The Stripping of the Altars: Traditional Religion in England, 1400-1580 (New Haven and London, 1992), 38-9; 260-1. For other analyses on the Virgin's Lament in the middle ages see Sarah Stanbury, 'The Virgin's Gaze: Spectacle and Transgression in Middle English Lyrics of the Passion', PMLA 1083-93; Donna Spivey Ellington, 'Impassioned Mother or Passive Icon: The Virgin's Role in Late Medieval and 
Early Modern Passion Sermons', Renaissance Quarterly 48 (1995): 227-62; Alexandra E. Johnston, 'Acting Mary: The Emotional Realism of the Mature Virgin in the N-Town Plays', From Page to Performance: Essays in Early English Drama, John A. Alford (ed) (East Lansing, 1995), 85-90.

16 For an elucidation of this doctrine and the counter-reformation reconsideration of it, see Harvey E. Hamburgh, 'The Problem of Lo Spasimo of the Virgin in Cinquecento Paintings of the Descent from the Cross', Sixteenth Century Journal XII (1981): 45-74.

17 With the exception of Rosemary Woolf and Kathleen Ashley, scholars have generally ignored this shift in emphasis. See Rosemary Woolf, The English Mystery Plays (Berkeley, 1972), 227; Kathleen M. Ashley, 'The Resurrection of Lazarus in the Late Medieval English and French Cycle Drama', Papers on Language and Literature 22 (1986): 227-44.

18 The Book of the City of Ladies, trans Earl Jeffrey Richards (New York: Persea, 1982), 27.

19 See Sandra McEntire, 'The Doctrine of Compunction From Bede to Margery Kempe', The Medieval Mystical Tradition in England, vol 4, 1987.

20 'Basil of Seleucia's Homily on Lazarus: A New Edition', Mary B. Cunningham (ed and trans), Analecta Bollandiana 104 (1986): 161-84 at 180.

21 Middle English Sermons, Woodburn O. Ross (ed), (London, 1960), 272.

22 David Mills, 'Approaches to Medieval Drama', Leeds Studies in English ns 3 (1969), 60 n14; cited in Peter Travis, Dramatic Design in the Chester Cycle (Chicago: University of Chicago Press, 1982), 162n25.

23 Lawrence Clopper, Drama, Play, and Game: English Festive Culture in the Medieval and the Early Modern Period (Chicago and London, 2001), 245.

24 Alexandra Johnston, 'The Christ Figure in the Ministry Plays of the Four English Cycles', $\mathrm{PhD}$ thesis (University of Toronto, 1964); cited in Travis $162 \mathrm{n} 25$.

25 'Lord, if you had been here, my brother would not have died' (John 11:32).

26 'Tunc venient Judei, quorum dicat Primus' (rubric between 425-6).

27 See Margery Kemp, The Book of Margery Kempe, Lynn Staley (ed) Medieval Institute Publications (Kalamazoo, 1996). Every year on Good Friday, for the ten years that her gift of tears consumes her, she weeps and sobs 'five er six owyrs togedyr' (57.3320). She weeps an hour 'for the sowles in Purgatory; an other owr for hem that weryn in myschefe, in poverte, er in any dises; an other owr for Jewys, Sarasinys, and alle fals heretikys that God for hys gret goodnes schulde puttyn awey her blyndnes that thei myth thorw hys grace be turnyd to the feyth of Holy Chirche and ben children of salvacyon' (57.3326-30). To 


\section{Katharine Goodland}

Margery, weeping and prayer are both 'ful swet and acceptabil' to God (78..4417).

28 Allen J. Frantzen, 'St. Erkenwald and The Raising of Lazarus', Mediaevalia 7 (1981): $157-71$ at 160.

29 The Oxford English Dictionary, s.v. 'bande'.

30 John 11:35 reads simply 'Et lacrimatus est jesus'.

31 Seth D. Riemer, 'The Dramatic Significance of Christ's Tears in a French and an English Version of the Lazarus Play', in Early Drama to 1600, Acta XIII (1985): 37-47.

32 See Kathleen M. Ashley, 'The Resurrection of Lazarus in the Late Medieval English and French Cycle Drama'. Papers on Language and Literature 22 (1986): 227-44; Barbara Gusick, 'Time and Unredemption: Perceptions of Christ's Work in the Towneley Lazarus', Fifteenth-Century Studies 22 (1995): 19-41.

33 See Laura Severt King, 'Sacred Eroticism, Rapturous Anguish: Christianity's Penitent Prostitutes and the Vexation of Allegory, 1370-1608', PhD thesis, (University of California, Berkeley, 1993), 75-176.

34 See Phillippy, Women, Death and Literature. 